\title{
Effects of W Alloying on the Lattice Distortion and Wear Behavior of Laser Cladding AlCoCrFeNiW $x$ High-Entropy Alloy Coatings
}

\author{
Tao Wu ${ }^{1,2}$, Yunxiang Chen ${ }^{1}$, Shuqin Shi ${ }^{1}$, Mengting $\mathrm{Wu}^{1}$, Wanyuan Gui ${ }^{2},{ }^{*}$, Yuanyuan Tan ${ }^{3}$, Jiheng Li ${ }^{4}$ \\ and Yuan $\mathrm{Wu}^{4, *}$ \\ 1 Zhejiang Institute of Mechanical \& Electrical Engineering, Hangzhou 310053, China; \\ wutao2@zime.edu.cn (T.W.); chenyunxiang@zime.edu.cn (Y.C.); shishuqin1963@126.com (S.S.); \\ wmtwmt968@163.com (M.W.) \\ 2 National Center for Materials Service Safety, University of Science and Technology Beijing, \\ Beijing 100083, China \\ 3 State Key Laboratory of Nonlinear Mechanics, Institute of Mechanics, Chinese Academy of Sciences, \\ Beijing 100190, China; yuanyuantan@lnm.imech.ac.cn \\ 4 State Key Laboratory of Advanced Metals and Materials, University of Science and Technology Beijing, \\ Beijing 100083, China; lijh@ustb.edu.cn \\ * Correspondence: guiwy@ustb.edu.cn (W.G.); wuyuan@ustb.edu.cn (Y.W.)
}

Citation: Wu, T.; Chen, Y.; Shi, S.; Wu, M.; Gui, W.; Tan, Y.; Li, J.; Wu, Y. Effects of W Alloying on the Lattice Distortion and Wear Behavior of Laser Cladding $\mathrm{AlCoCrFeNiW}_{x}$ High-Entropy Alloy Coatings. Materials 2021, 14, 5450. https:// doi.org/10.3390/ma14185450

Academic Editor: Tao-Hsing Chen

Received: 20 July 2021

Accepted: 15 September 2021

Published: 21 September 2021

Publisher's Note: MDPI stays neutral with regard to jurisdictional claims in published maps and institutional affiliations.

Copyright: (c) 2021 by the authors. Licensee MDPI, Basel, Switzerland. This article is an open access article distributed under the terms and conditions of the Creative Commons Attribution (CC BY) license (https:/ / creativecommons.org/licenses/by/ $4.0 /)$.

\begin{abstract}
Friction and wear properties of hot working die steel at above $800{ }^{\circ} \mathrm{C}$ are of particular interest for high temperature applications. Here, novel AlCoCrFeNiW $x$ high-entropy alloy (HEA) coatings have been fabricated on the surface of hot working die steel by laser cladding. The effects of the as-prepared $\mathrm{AlCoCrFeNiW} x \mathrm{HEA}$ coatings on the microstructure and high temperature friction and wear behavior of hot working die steel are investigated through scanning electron microscopy (SEM), electron probe microanalysis (EPMA), X-ray diffraction (XRD), and X-ray absorption fine structure (XAFS). Having benefited from the formation of $\mathrm{W}$-rich intermetallic compounds after the addition of $\mathrm{W}$ elements, the high temperature wear resistance of the coatings is obviously improved, and friction coefficient shows a large fluctuation. The microstructural characteristics of

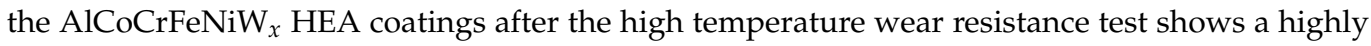
favorable impact on microstructure stability and wear resistance, due to its the strong lattice distortion effect of W element on BCC solid solutions and the second phase strengthening of the W-rich intermetallic compounds. These findings may provide a method to design the high temperature wear resistant coatings.
\end{abstract}

Keywords: laser cladding; high-entropy alloy; coating; lattice distortion; high temperature wear behavior

\section{Introduction}

Currently, hot working die steel is widely used in tooling applications, including die casting, hot extrusion, hot forging, and hot stamping, due to its unique features including high strength and hardness [1-5]. The die surface has to withstand substantial cyclic mechanical and thermal stress, adhesion and abrasion, as well as thermal dissolution in its service process, and is often failed by repeated thermal wear and thermal fatigue [3-5]. Therefore, advanced surface modifications are required before the die surface can be effectively applied in practice, such as electroplating, diffusion treatment, chemical vapor deposition, cold spray, and laser cladding [6-13]. Advanced surface modification technologies can dramatically boost energy efficiency as well as improve product performance and quality [8]. Compared with other surface modification technologies, laser cladding shows great advantages in the preparation of the wear-resistance surface, as it can generate strong metallurgical bonding between cladding layers and substrate, and because of its low coating dilution rate and small thermal effect of substrate [10-13]. 
HEA are a class of materials that contain 5-13 principal elements in near-equiatomic proportions; they have attracted a wide range of interesting research due to their excellent mechanical properties [14]. In recent years, a variety of HEA were reported publicly in the literature [15-19]. Among them, AlCoCrFeNi HEA composed of a single BCC solid solution phase shows excellent corrosion resistance and has great potential for surface coating applications [13,17,19-22]. However, an insufficient high temperature wear-resistance of AlCoCrFeNi HEA greatly limits their practical applications at elevated temperatures (above $800{ }^{\circ} \mathrm{C}$ ). According to the principle of dispersion strength, the strength and hardness of the simple solid solution phases could be improved further by the precipitated intermetallic compound phases. From the perspective of the dispersion strengthening mechanism, WC, TiC ceramic particles are commonly used as reinforcement phases in high-entropy alloys $[10,12,23]$. These granular-shaped precipitates can improve the microhardness and wear resistance of the coating. Unfortunately, it is easy to introduce cracks and defects in the laser cladding process if there are huge difference between the thermal expand coefficient of coating and that of substrate [10,12,23].

To overcome the aforementioned shortcomings, we offer an alternative approach for fabricating high temperature wear resistant HEA coatings on $\mathrm{H} 13$ hot working die steel. The introduction of $\mathrm{W}$ in the AlCoCrFeNi HEA system provides a potential solution for high temperature application because of its high melting point, low coefficient of thermal expansion, and good creep resistance [24,25]. More specifically, the introduction of W does not change the original phase composition of HEA [25]. Therefore, the performance of AlCoCrFeNi HEA is expected to be enhanced via introducing W particles. In this work, the $\mathrm{AlCoCrFeNiW} x(x=0,0.5$ and 1$)$ HEA coatings were fabricated by laser cladding on hot working die steel. The morphology of the microstructure and chemical composition of micro-areas were investigated in detail. The wear resistance of the coatings was tested at a high temperature, and then the wear mechanism of the worn surfaces was analyzed. We proved that the microstructure becomes more stable and enhances wear resistance of AlCoCrFeNiWx HEA on H13 steel by the strong lattice distortion effect of W element on BCC solid solutions and the second phase strengthening of the W-rich intermetallic compounds.

\section{Experimental Section}

\subsection{Fabrication of AlCoCrFeNiW $\mathrm{HEA} \mathrm{Coatings}$}

The commercial AlCoCrFeNi HEA powder with the nominal size range of 45-105 $\mu \mathrm{m}$ and the $W$ particles with the nominal size range of 5-20 $\mu \mathrm{m}(99.9 \%$ purity) were used to perform the subsequent laser cladding process, as shown in Figure 1. All powders were supplied by Jiangsu Vilory Advanced Materials Technology Co., Ltd. (Xuzhou, China). The chemical composition of AlCoCrFeNi HEA powder used in our experiments was shown in Table 1. For preparation of the AlCoCrFeNi HEA coatings, the commercial W particles powder with an atomic ratio of (0, 0.5 and 1$)$ was mixed with AlCoCrFeNi HEA powder by ball milling (QM-3SP2 planetary, Changsha Deco Instrument Equipment Co., LTD, Changsha, China) with $300 \mathrm{rpm}$ in a ball mill jar for $8 \mathrm{~h}$ (ball-to-powder weight ratio 3:1). Then, the mixed powders were dried under vacuum conditions $\left(80{ }^{\circ} \mathrm{C}\right.$ for $\left.1.5 \mathrm{~h}\right)$ for vapor evaporation. Samples of the H13 steel were cut into pieces $10 \mathrm{~cm} \times 10 \mathrm{~cm} \times 0.5 \mathrm{~cm}$ in size. $\mathrm{SiC}$ paper with grit \#150 was used to grind the H13 steel samples. The HEA coatings with composition of $\mathrm{AlCoCrFeNiW}_{x}(x=0,0.5$ and 1$)$ were fabricated by laser cladding under an input laser power of $3000 \mathrm{~W}$ (one-layer HEA coatings with the thickness of coating being about $1 \mathrm{~mm}$, and the overlapping between multiple channels about $40 \%$ ). The scanning rate was adjusted into $6 \mathrm{~mm} / \mathrm{s}$, and a spot diameter was $3 \mathrm{~mm}$ after optimization to ensure the absence of cracks and pores in the coatings. In addition, high purity argon (99.9\%) was used as a protective gas. 


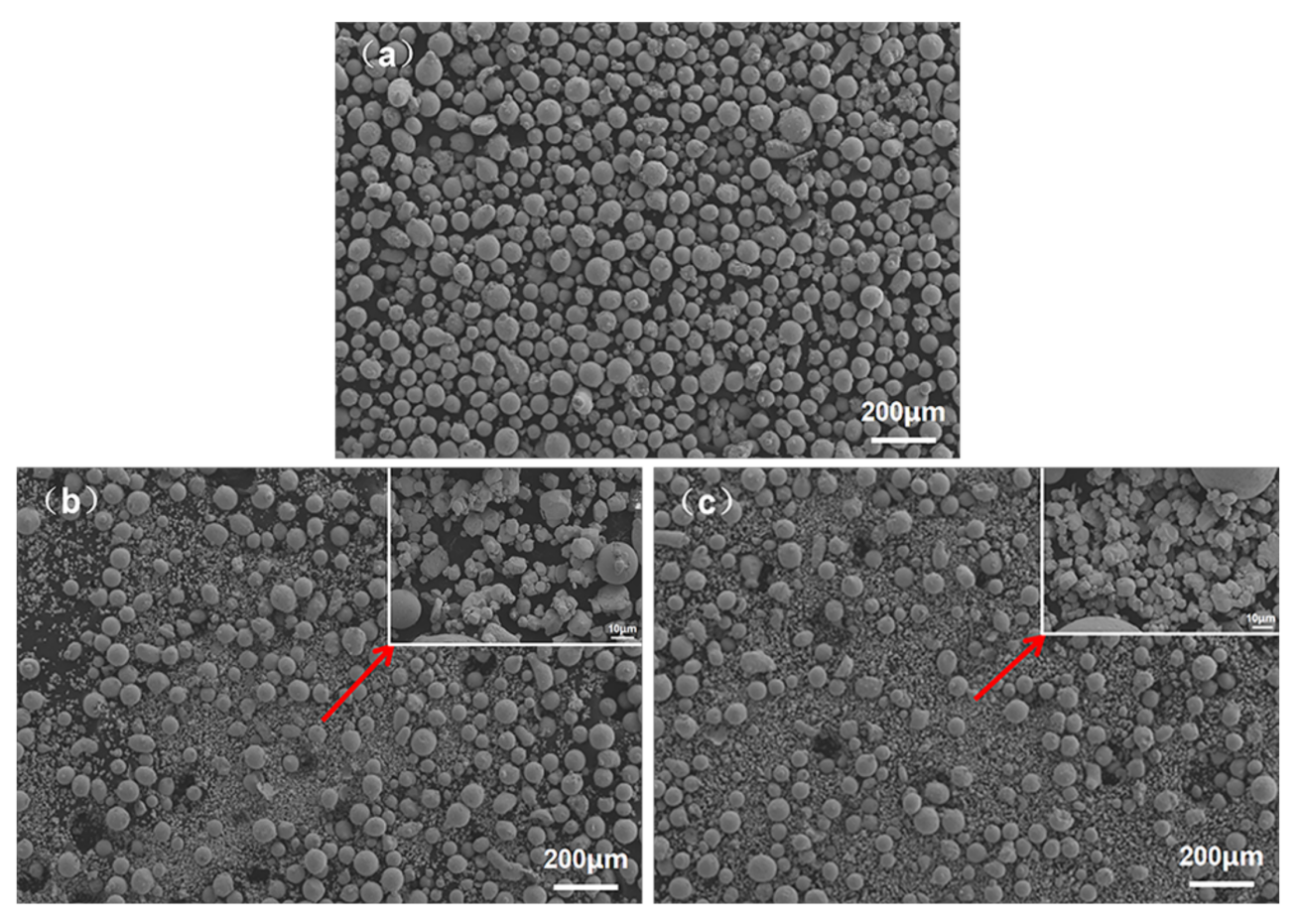

Figure 1. FESEEM images of the AlCoCrFeNiW $x$ HEA powder: (a) $x=0,(\mathbf{b}) x=0.5$, (c) $x=1$.

Table 1. The chemical composition of AlCoCrFeNi HEA powder.

\begin{tabular}{ccc}
\hline & Element & Tested \\
& $\mathrm{Al}$ & 10.66 \\
Element Compositions/wt.\% & $\mathrm{Co}$ & $\mathrm{Bal}$. \\
& $\mathrm{Cr}$ & 20.51 \\
& $\mathrm{Fe}$ & 22.06 \\
& $\mathrm{Ni}$ & 22.99 \\
\hline \multirow{2}{*}{ Oxygen and Nitrogen content } & $\mathrm{O} / \mathrm{ppm}$ & 212 \\
& $\mathrm{~N} / \mathrm{ppm}$ & 99 \\
\hline \multirow{3}{*}{ Particle size distribution } & $\mathrm{D} 10 / \mu \mathrm{m}$ & 21.0 \\
& $\mathrm{D} 50 / \mu \mathrm{m}$ & 35.1 \\
& $\mathrm{D} 90 / \mu \mathrm{m}$ & 54.2 \\
\hline
\end{tabular}

\subsection{Materials Characterization and High Temperature Friction and Wear Properties}

Field emission scanning electron microscopy (FESEM, Zeiss Supra 55, Carl Zeiss AG, Oberkochen, Germany) was performed for morphology observations at an acceleration voltage of $15 \mathrm{kV}$. The samples' surface composition analysis was performed via energy dispersive spectrometry (EDS) with a take-off angle of $36.5^{\circ}$ and live time of $2 \mathrm{~min}$ to further enhance the EDS precision for quantification. The phase identifications were investigated using X-ray diffractometer (XRD, PANalytical X'Pert Pro, PANalytical B.V, Alemlo, Netherlands) with $\mathrm{Cu} K \alpha$ radiation operated at a voltage of $40 \mathrm{kV}$ at room temperature, a tube current of $40 \mathrm{~mA}$, and a scanning rate of $10^{\circ} / \mathrm{min}$, the slit width at the X-ray emitting end is $10 \mathrm{~mm} \times 10 \mathrm{~mm}$ and at the lead skin window of the receiver is $8 \mathrm{~mm} \times 20 \mathrm{~mm}$. The coating surface was also examined by using energy dispersive spectrometer (EDS, Genesis Edax, Carl Zeiss AG, Oberkochen, Germany). XAFS data were collected in transmission mode from $\mathrm{K}$ edges of $\mathrm{Co}, \mathrm{Cr}, \mathrm{Fe}, \mathrm{Ni}$ and $\mathrm{W}$ at 4B9A stations in Beijing Synchrotron Radiation Facility (BSRF, Beijing, China). High temperature friction and wear properties of the AlCoCrFeNi HEA coatings were measured by BRUKER UMT-TRIBOLAB (Beijing, China) friction and wear test. The $\mathrm{Si}_{3} \mathrm{~N}_{4}$ grinding head was used in the test, the loading force was $5 \mathrm{~N}$, the sliding friction frequency was $5 \mathrm{~Hz}$, the friction stroke was $1 \mathrm{~cm}$, the test temperature was $800{ }^{\circ} \mathrm{C}$ and friction time was $60 \mathrm{~min}$. The width and depth of wear marks 
were measured by RTEC UP (Bruker. Karlsruhe, Germany) series optical profilometer instruments.

\section{Results and Discussion}

\subsection{Phase Composition and Microstructure Feature}

XRD patterns of $\mathrm{AlCoCrFeNiW}_{x}(x=0,0.5$ and 1$)$ HEA coatings are displayed in Figure 2. Initially, $\mathrm{AlNi}$ and BCC peaks apparently occur in the diffractogram of $\mathrm{AlCoCrFeNi}$ HEA, which are similar to the results of previous studies $[13,17]$. With a 0.5 at. $\% \mathrm{~W}$ particles addition, two new phases of AlW and W-rich intermetallic compounds are detected and the $\mathrm{AlCoCrFeNiW}$..5 HEA are primarily composed of AlNi, AlW, BCC, and W-rich intermetallic compounds. Upon increasing the mass of the added $\mathrm{W}$ particles (1 at.\%), the results are similar to those of the $\mathrm{AlCoCrFeNiW}_{x} \mathrm{HEA}$ with a 0.5 at. $\% \mathrm{~W}$ particles addition. Furthermore, because the atomic radius of $\mathrm{W}$ was larger than $\mathrm{Co}, \mathrm{Cr}, \mathrm{Fe}, \mathrm{Ni}$, the addition of $\mathrm{W}$ also caused the original lattice occupation to be distorted, which shows the shift of the peak position in the XRD patterns.

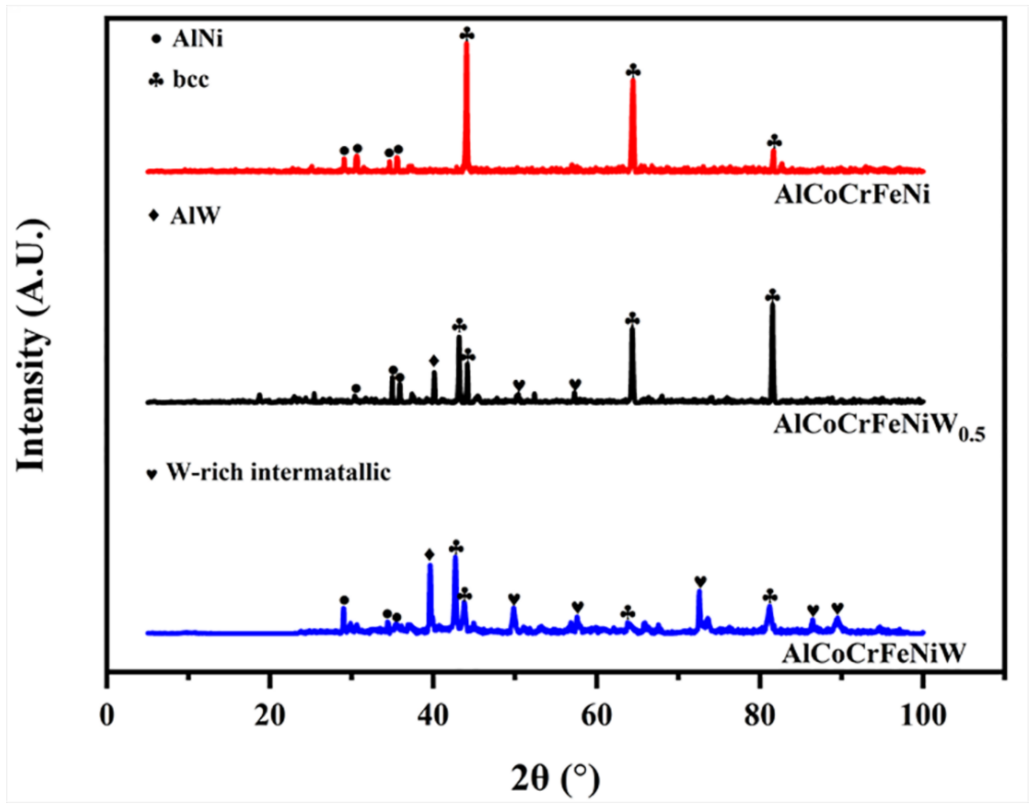

Figure 2. XRD patterns of $\mathrm{AlCoCrFeNiW}_{x}(x=0,0.5$ and 1$)$ HEA coatings.

Figure 3 depicts the surface and cross-sectional morphologies of the $\mathrm{AlCoCrFeNiW} x$ HEA coatings. The distinct differences are observed with regard to the surface morphologies of the AlCoCrFeNiW $x$ HEA coatings, as shown in Figure 3a,c,e. With a content of 0.5 at.\% of $\mathrm{W}$ powder addition, some white irregular floccules appeared. As the $\mathrm{W}$ powder increases from 0.5 at.\% to 1 at.\%, the white irregular floccules microstructures transform into white suspended sphere or near sphere particulate microstructures. The cross-sectional thickness of the $\mathrm{AlCoCrFeNiW} x$ HEA coatings is about $850 \mu \mathrm{m}$, as shown in Figure $3 b, d, f$. Without $W$ powder addition, there is a dense laser cladding structure with the thin 10-20 $\mu \mathrm{m}$ large micro-cracks and 1-2 $\mu \mathrm{m}$ black holes with horizontal distribution on the edge of substrate and coatings. With a content of 0.5 at.\% of $\mathrm{W}$ powder addition, the number of micro-cracks and black holes has significantly decreased. As the $\mathrm{W}$ powder increases from 0.5 at. $\%$ to 1 at. $\%$, there is a dense laser cladding structure with micro-cracks measuring hundreds of micrometers and $10-20 \mu \mathrm{m}$ pores with vertical distribution on the edge of substrate and coatings. 

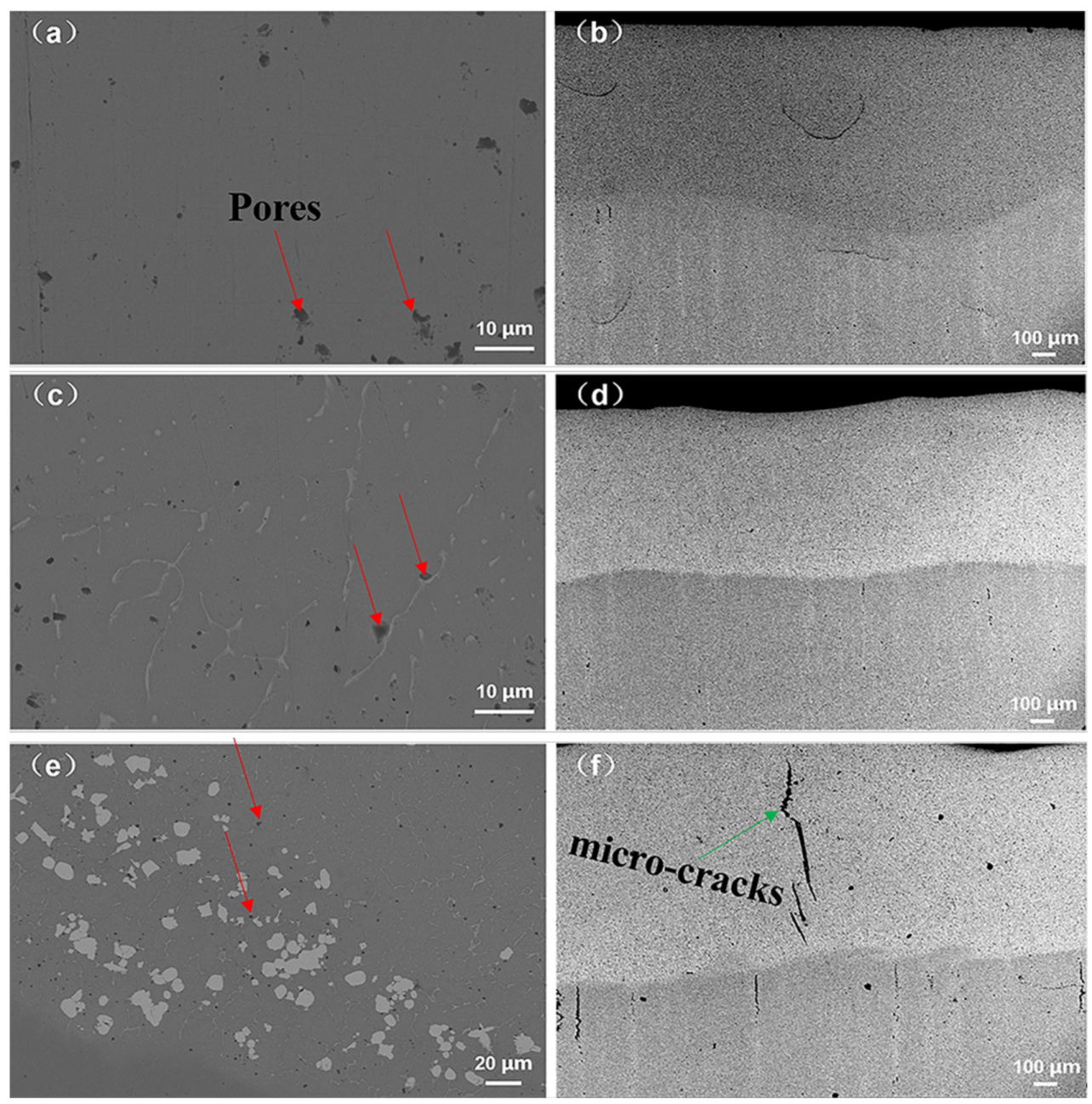

Figure 3. Surface and cross-sectional FESEEM images of the $\mathrm{AlCoCrFeNiW}_{x}$ HEA coatings: $(\mathbf{a}, \mathbf{b}) x=0,(\mathbf{c}, \mathbf{d}) x=0.5,(\mathbf{e}, \mathbf{f}) x=1$.

Figure 4 shows the EDS element mapping distribution of the AlCoCrFeNiW HEA coatings, the whole coatings are distributed with $\mathrm{W}, \mathrm{Cr}, \mathrm{Ni}, \mathrm{Fe}, \mathrm{Al}$, and Co elements. The EDS measurement is taken from the near upper surface of the AlCoCrFeNiW HEA coatings. Interestingly, the content of W element in white suspended sphere or near sphere particulate microstructure is much higher than other parts, suggesting that the white suspended sphere or near sphere particulate microstructure could be W-rich intermetallic compounds. In addition, the content of $\mathrm{Al}$ element around pores is much higher than other parts, indicating that the regions around pores were rich in $\mathrm{Al}$ element. The formation of the pores in coatings can be ascribed to the volatilization and oxidation of the $\mathrm{Al}$ element during the laser cladding process (the melting point of $\mathrm{Al}$ is significantly lower than that of other metals). 


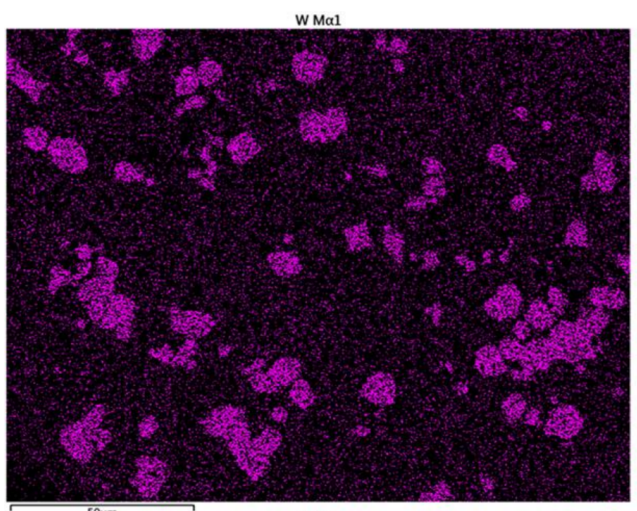

Cr Kal
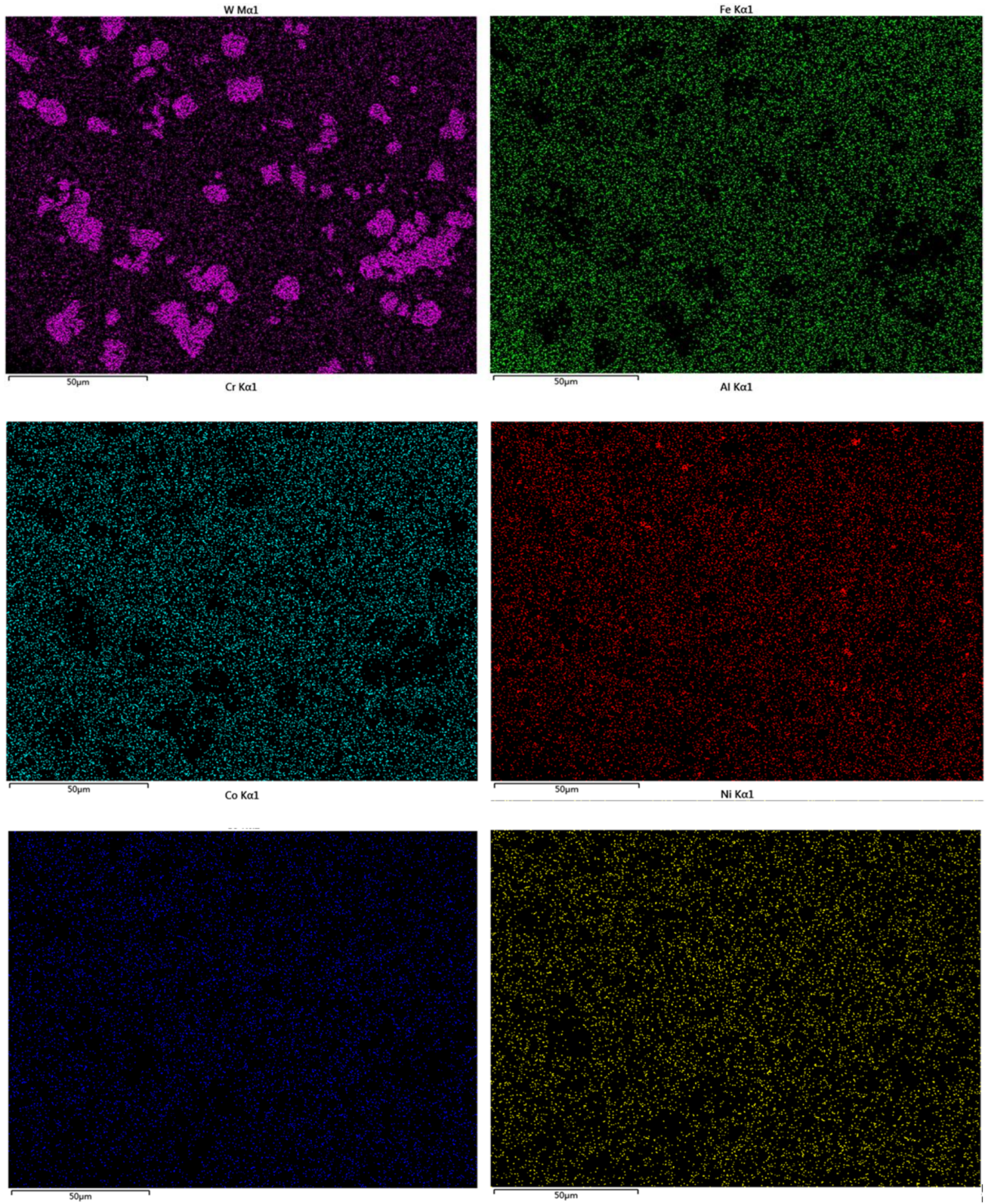

Figure 4. EDS element mapping of AlCoCrFeNiW HEA coatings on $\mathrm{H} 13$ steel. 


\subsection{Lattice Distortion of AlCoCrFeNiW HEA Coatings Obtained by EXAFS Analysis}

Lattice distortion results in an increase in the material internal energy and the microscopic stress, and hinders the dislocation slip deformation, making the material strength and hardness increase [14,15]. To understand the lattice distortion of $\mathrm{AlCoCrFeNiW}_{x} \mathrm{HEA}$ coatings, an X-ray absorption fine structure (EXAFS) technique $[26,27]$ was adopted, and EXAFS measurement was taken from the near upper surface of the AlCoCrFeNiW HEA coatings. Figure 5 shows the Fourier transforms spectra from EXAFS K-edges of different elements of the standard sample and the $\mathrm{AlCoCrFeNiW}_{x}(x=0,0.5$ and 1) HEA coatings). The EXAFS data of $\mathrm{Co}, \mathrm{Ni}, \mathrm{Cr}$ and $\mathrm{Fe}$ K-edges were analyzed by using the Demeter software package (Univ. of Chicago) [28]. The reference spectra of their K-edges were calculated from the corresponding crystal structures by using FEFF8 code (Univ. of Washington) [29]. As shown in Figure $5 \mathrm{a}-\mathrm{d}$, the Fourier transforms spectral peak positions of all elements in $\mathrm{AlCoCrFeNiW}_{x}$ HEA coatings which are significantly deviated from that of the standard sample, indicating the huge lattice distortion in the $\mathrm{AlCoCrFeNiW}_{x} \mathrm{HEA}$ coatings. It is noted that $\mathrm{Co}$ has negative deviation in $\mathrm{AlCoCrFeNiW}_{x}(x=0)$ HEA coatings, while $\mathrm{Ni}, \mathrm{Cr}$ and Fe have similar positive deviation, as the $\mathrm{W}$ powder mass increases from 0 to $1 \mathrm{at} . \%$, Co has the largest deviation or distortion, Ni has the lowest deviation. Overlapping of EXAFS peaks stems from the amplitude contribution of neighbor atoms and a photoelectron focusing effect caused by the collinear arrangement of the lattice sites [30]. These negative and positive deviations illustrate that the lattice of $\mathrm{AlCoCrFeNiW}_{x}$ HEA coatings is distorted at every lattice site, since each kind of atom has some offset from the lattice sites. Deviation of peak position for $\mathrm{Co}, \mathrm{Ni}, \mathrm{Cr}$ and $\mathrm{Fe}$ could affect the collinear arrangement of the lattice sites, leading to further alteration of overlapping. In fact, the peak position deviation and the difference of atom spatial distribution of HEA alloys is closely related to atom size and crystal structure in pure metal and chemical bond differences in alloys. The atomic sizes of $\mathrm{Al}, \mathrm{Co}, \mathrm{Cr}, \mathrm{Fe}, \mathrm{Ni}$ and $\mathrm{W}$ are listed in Table 2. Obviously, the appreciable larger atomic size of $\mathrm{W}$ and $\mathrm{Al}$ causes the peak deviation of neighboring atoms. Reasons for peak deviations of $\mathrm{Co}, \mathrm{Ni}, \mathrm{Cr}$ and $\mathrm{Fe}$ after $\mathrm{W}$ alloying are the combined effect of appreciable atomic size, crystal structure, and chemical bonding differences. Through the high-entropy effect during alloying process, the solid solutions are crystalline, and the atoms are strongly displaced with respect to their regular location in an undistorted lattice, these results are similar to the results reported by Miracle and Senkov [31]. It was concluded that a distribution of bond length must exist in the random alloy in order for the distorted first shell of neighbors to be accommodated.

Table 2. Atomic size of HEA coatings' elements (Al, $\mathrm{Co}, \mathrm{Cr}, \mathrm{Fe}, \mathrm{Ni}, \mathrm{W}$ ).

\begin{tabular}{ccccccc}
\hline Samples & Al & Co & Cr & Fe & Ni & W \\
\hline Atomic size $/ \AA$ & 1.43 & 1.25 & 1.30 & 1.26 & 1.24 & 1.41 \\
\hline Crystal structure & \multicolumn{7}{c}{ HCP } & & & \\
\hline
\end{tabular}



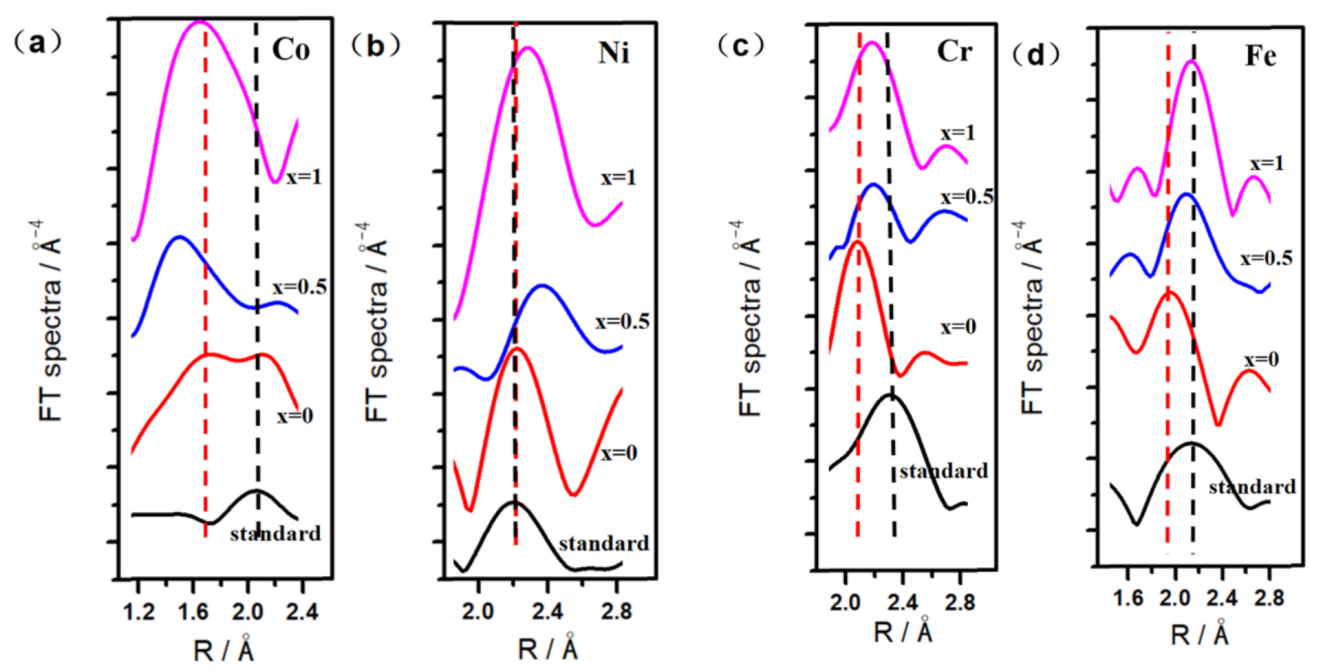

Figure 5. Fourier transforms spectra from EXAFS K-edges of different elements in $\mathrm{AlCoCrFeNiW}_{x}$ HEA coatings: (a) Co, (b) $\mathrm{Ni}$, (c) $\mathrm{Cr},(\mathbf{d}) \mathrm{Fe}$.

\subsection{High Temperature Friction and Wear Properties of HEA Coatings}

Figure 6 shows the influence of the $\mathrm{W}$ powder addition on the high temperature friction and wear properties of the $\mathrm{AlCoCrFeNiWx}$ coatings on $\mathrm{H} 13$ steel. The $\mathrm{H} 13$ steel exhibits a maximum friction coefficient and wear loss after $800^{\circ} \mathrm{C} / 60 \mathrm{~min}$ high temperature friction and wear treatment. Compared to the $\mathrm{H} 13$ steel, all HEA coatings exhibit smaller friction coefficient and wear loss. A minimum friction coefficient and wear loss (only $12 \%$ of $\mathrm{H} 13$ steel wear loss) occurs in the $\mathrm{AlCoCrFeNiW}_{\mathrm{x}}$ with the addition of 0.5 at. $\% \mathrm{~W}$. Consequently, a great improvement in the high temperature friction and wear resistance is achieved by the addition of the $\mathrm{W}$ powder and is likely due to the lattice distortion becoming more remarkable; the unmelted $\mathrm{W}$-rich particles also improve the wear resistance as the hard phase.
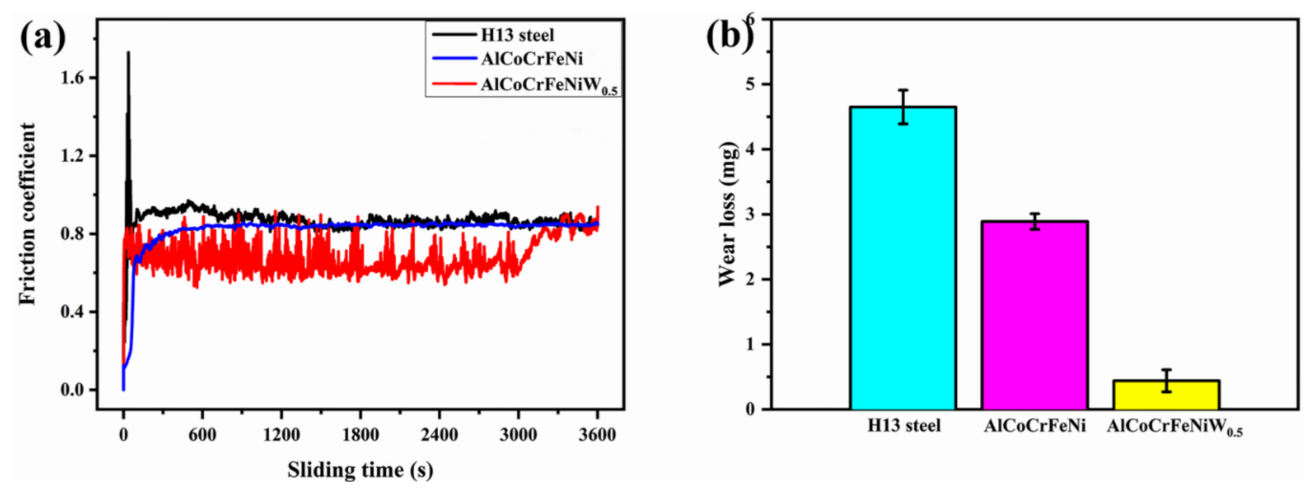

Figure 6. (a) The high temperature friction coefficient curves: $\mathrm{H} 13$ steel (black), AlCoCrFeNi (blue), $\mathrm{AlCoCrFeNiW}_{0.5}$ (red); (b) High temperature wear loss: H13 steel (cyan), AlCoCrFeNi (purple), $\mathrm{AlCoCrFeNiW}_{0.5}$ (yellow).

The addition of 0.5 at. $\% \mathrm{~W}$ powder in $\mathrm{AlCoCrFeNi} \mathrm{HEA} \mathrm{system} \mathrm{can} \mathrm{improve} \mathrm{its} \mathrm{high}$ temperature friction and wear resistance. These results are also supported by wear scars height and width of samples. The distinct differences are observed with regard to threedimensional morphologies, as shown in Figure 7. After $800{ }^{\circ} \mathrm{C} / 60 \mathrm{~min}$ high temperature friction and wear treatment, the $\mathrm{H} 13$ steel exhibits a maximum height and width, however the $\mathrm{AlCoCrFeNiW}_{0.5}$ coatings exhibit a minimum height and width. For $\mathrm{H} 13$ steel, there are higher and wider wear scars on its surface. Wear scars height and width of $\mathrm{H} 13$ steel, $\mathrm{AlCoCrFeNi}$ and $\mathrm{AlCoCrFeNiW} 0.5$ coatings after $800{ }^{\circ} \mathrm{C} / 60 \mathrm{~min}$ high temperature friction and wear test are listed in Table 3. 

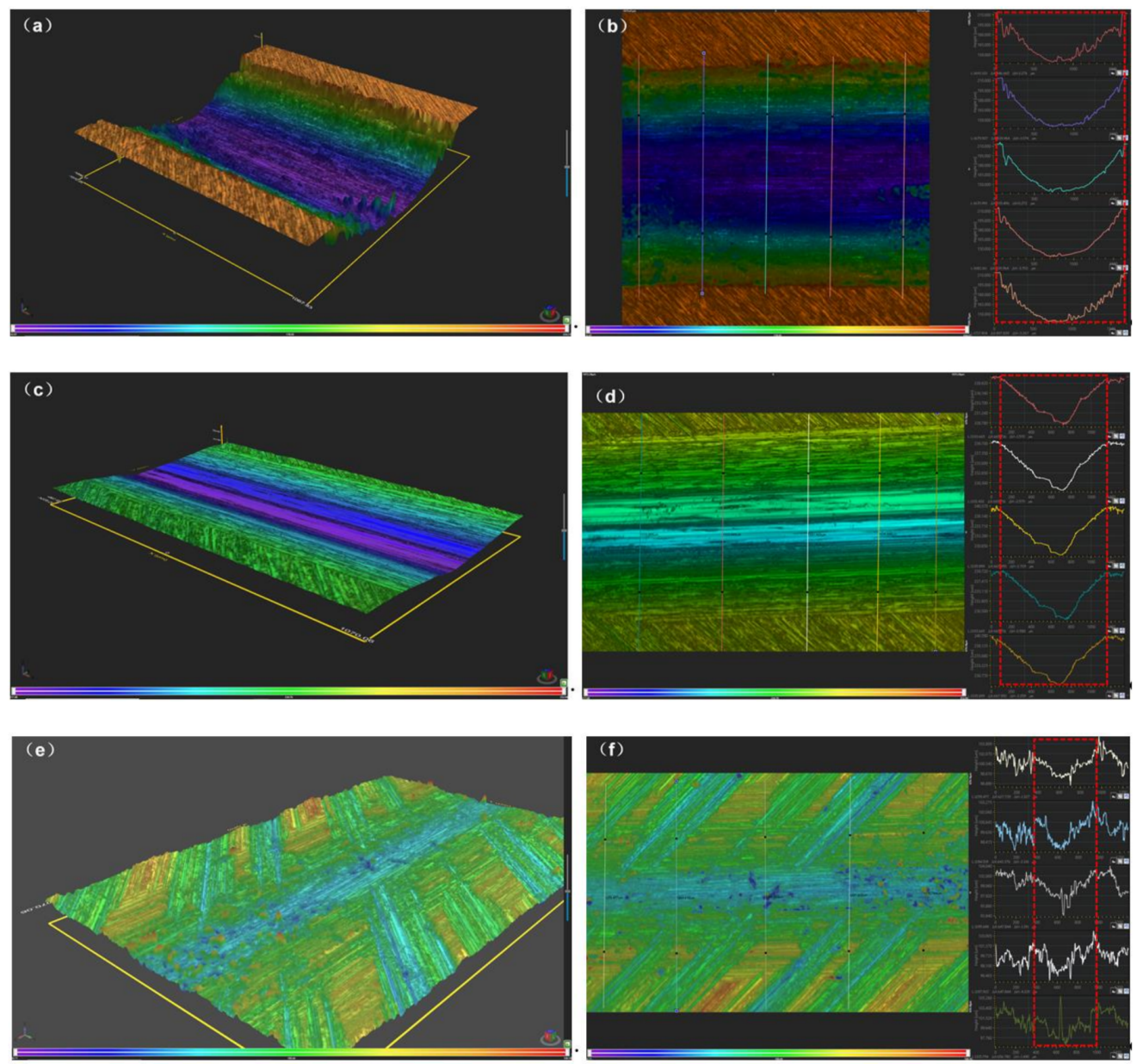

Figure 7. Three-dimensional morphologies and height analysis of the wear scars of samples after $800{ }^{\circ} \mathrm{C} / 60$ min friction and wear tests: (a,b) H13 steel; (c,d) AlCoCrFeNi coating; (e,f) $\mathrm{AlCoCrFeNiW}, 0.5$ coating.

Table 3. Wear scars height and width of $\mathrm{H} 13$ steel, $\mathrm{AlCoCrFeNi}$ and $\mathrm{AlCoCrFeNiW}{ }_{0.5}$ coatings after $800{ }^{\circ} \mathrm{C} / 60 \mathrm{~min}$ high temperature friction and wear test.

\begin{tabular}{ccc}
\hline Samples & Height & Width \\
\hline H13 steel & $75.50 \mu \mathrm{m}$ & $1550 \mu \mathrm{m}$ \\
\hline AlCoCrFeNi coating & $11.38 \mu \mathrm{m}$ & $975 \mu \mathrm{m}$ \\
\hline AlCoCrFeNiW $_{0.5}$ coating & $6.80 \mu \mathrm{m}$ & $355 \mu \mathrm{m}$ \\
\hline
\end{tabular}

The worn surfaces microstructure of the $\mathrm{AlCoCrFeNi}$ and $\mathrm{AlCoCrFeNiW}$. 0.5 coatings at $800^{\circ}$ Care presented in Figure $8 \mathrm{a}, \mathrm{b}$. The discontinuous distribution of the adhesive layer represents the occurrence of adhesive wear during the wear process. Obvious plastic deformation occurred on both surfaces of $\mathrm{AlCoCrFeNi}$ and $\mathrm{AlCoCrFeNiW} 0.5$ coatings. Strong resistance of high temperature softening induced by dynamic recrystallization (involving dislocation tangles, and formation of dislocation cell structures and sub-grains) in the BCC HEA was reported recently, which indicates that dislocation tangles, and formation of dislocation cell structures and sub-grains play an importance role in the high temperature mechanical properties [32]. According to Orowan's strengthening mechanism, lattice distortion can increase lattice stress. Lattice distortion of BCC phase for $\mathrm{AlCoCrFeNiW}_{0.5} \mathrm{HEA}$ coating also plays a contributory role. Therefore, the BCC phase in the $\mathrm{AlCoCrFeNiW}_{0.5}$ coating has better resistance to damage under the same external forces at high temperatures. 
Moreover, the W-rich hard phases also contribute to improving the plastic deformation resistance of the matrix.
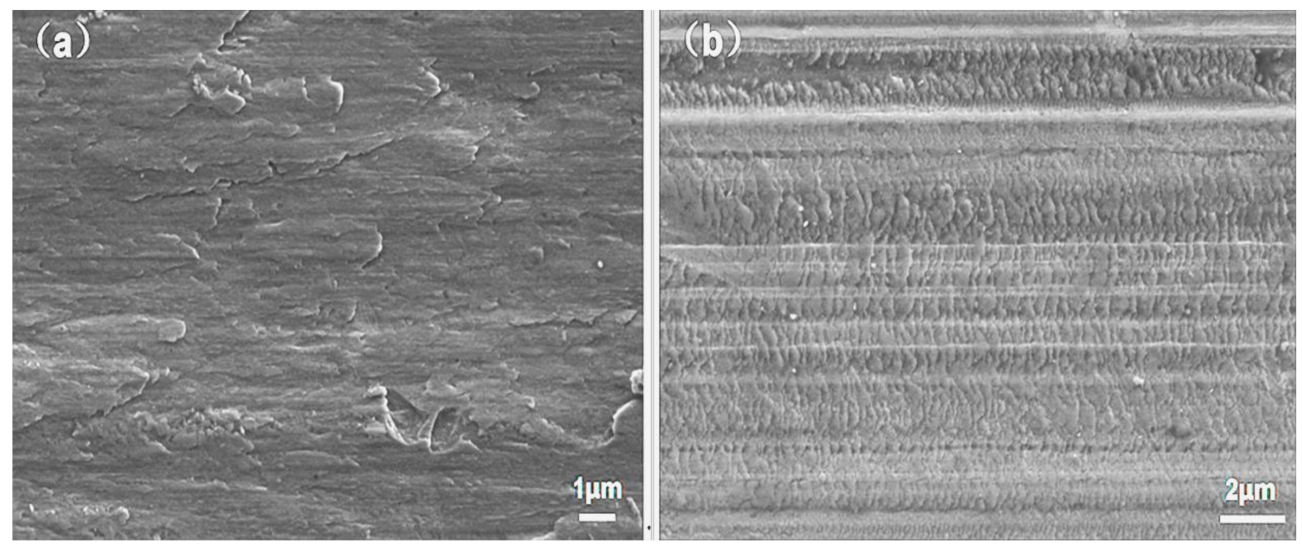

Figure 8. SEM images of the worn surfaces of HEA coatings after $800{ }^{\circ} \mathrm{C} / 60 \mathrm{~min}$ friction and wear tests: (a) AlCoCrFeNi coating; (b) $\mathrm{AlCoCrFeNiW}_{0.5}$ coating.

\section{Conclusions}

AlCoCrFeNiW $x(x=0,0.5,1)$ HEA coatings with a thickness of approximately $850 \mu \mathrm{m}$ were successfully fabricated by laser cladding on $\mathrm{H} 13$ steels. Compared with $\mathrm{AlCoCrFeNi}$ HEA coatings with BCC phase, the addition of 0.5 at. $\% \mathrm{~W}$ powder induces the favorable formation of W-rich intermetallic compounds and BCC phase in $\mathrm{AlCoCrFeNiW}_{0.5} \mathrm{HEA}$ coatings. After $800{ }^{\circ} \mathrm{C} / 60 \mathrm{~min}$ friction and wear tests, the $\mathrm{AlCoCrFeNiW}_{0.5}$ HEA coatings exhibit a best high temperature wear consistency, due to the synergy effect of phase transformation and lattice distortion. Thus, the $\mathrm{AlCoCrFeNiW}_{0.5}$ HEA coatings achieve a minimum friction coefficient and wear loss (only $12 \%$ of $\mathrm{H} 13$ steel wear loss). These findings make noteworthy progress towards enhancing high temperature wear resistance of AlCoCrFeNi HEA coatings by laser cladding.

Author Contributions: The idea was proposed by T.W., Y.C., J.L. and Y.W. The experiments were carried out by T.W. and M.W. The experimental results were analyzed and interpreted by T.W., W.G., S.S. and Y.T. T.W. and W.G. worte the main manuscript text. The manuscript was reviewed and further analyzed by T.W., W.G. and Y.W. All authors have read and agreed to the published version of the manuscript.

Funding: This research received no external funding. This research was funded by [State Key Lab of Advanced Metals and Materials] grant number [No. 2020-Z07], [Zhejiang Provincial Natural Science Foundation] grant number [No. LGG21E010005], [Science and Education Integration Project of ZIME] grant number [No. A-0271-20-204]; [Fundamental Research Funds for the Central Universities] grant number [No. FRF-TP-19-080A1]; and [China Postdoctoral Science Foundation] grant number [No. 2019M660452].

Institutional Review Board Statement: Not applicable.

Informed Consent Statement: Not applicable

Data Availability Statement: The authors declare that the data supporting the findings of this study are available within the paper.

Conflicts of Interest: The authors declare no competing interests.

\section{References}

1. Bailey, N.S.; Katinas, C.; Shin, Y.C. Laser direct deposition of AISI H13 tool steel powder with numerical modeling of solid phase transformation, hardness, and residual stresses. J. Mater. Process. Tech. 2017, 247, 223. [CrossRef]

2. Cong, D.L.; Zhou, H.; Yang, M.Q.; Zhang, Z.H.; Zhang, P.; Meng, C.; Wang, C.W. The mechanical properties of H13 die steel repaired by a biomimetic laser technique. Opt. Laser Technol. 2013, 53, 1. [CrossRef] 
3. Telasang, G.; DuttaMajumdar, J.; Padmanabham, G.; Manna, I. Wear and corrosion behavior of laser surface engineered AISI H13 hot working tool steel. Surf. Coat. Tech. 2015, 26, 69. [CrossRef]

4. Telasang, G.; Majumdar, J.D.; Padmanabham, G.; Manna, I. Structure-property correlation in laser surface treated AISI H13 tool steel for improved mechanical properties. Mater. Sci. Eng. A 2014, 599, 255. [CrossRef]

5. Meng, C.; Zhou, H.; Zhang, H.F.; Tong, X.; Cong, D.L.; Wang, C.W.; Ren, L.Q. The comparative study of thermal fatigue behavior of H13 die steel with biomimetic non-smooth surface processed by laser surface melting and laser cladding. Mater. Des. 2013, 51, 886. [CrossRef]

6. Chen, R.R.; Gong, X.; Wang, Y.; Qin, G.; Zhang, N.N.; Su, Y.Q.; Ding, H.S.; Guo, J.J.; Fu, H.Z. Microstructure and oxidation behaviour of plasma-sprayed NiCoCrAlY coatings with and without Ta on Ti44Al6Nb1Cr alloys. Corros. Sci. 2018, 136, 244-254 [CrossRef]

7. Miyake, M.; Tajikara, S.; Hirato, T. Fabrication of $\mathrm{TiAl}_{3}$ coating on TiAl-based alloy by $\mathrm{Al}$ electrodeposition from dimethylsulfone bath and subsequent annealing. Surf. Coat. Tech. 2011, 205, 5141-5146. [CrossRef]

8. Gui, W.Y.; Hao, G.J.; Liang, Y.F.; Li, F.; Liu, X.; Lin, J.P. Surface modification by electrolytic plasma processing for high Nb-TiAl alloys. Appl. Surf. Sci. 2016, 389, 1161-1168. [CrossRef]

9. Gui, W.Y.; Qu, Y.H.; Zhang, H.; Lin, J.P. Cathode electrolytic plasma deposition of $\left(\mathrm{Al}_{0.9} \mathrm{Cr}_{0.1}\right)_{2} \mathrm{O}_{3} / \gamma-\mathrm{Al}_{2} \mathrm{O}_{3}$ composite coatings onto Ti45Al8.5Nb0.1Y0.2W alloys for high-temperature applications. Materialia 2021, 15, 101002. [CrossRef]

10. Liu, H.; Liu, J.; Chen, P.J.; Yang, H.F. Microstructure and high temperature wear behaviour of in-situ TiC reinforced AlCoCrFeNibased high-entropy alloy composite coatings fabricated by laser cladding. Opt. Laser Technol. 2019, 118, 140. [CrossRef]

11. Wen, X.; Cui, X.F.; Jin, G.; Zhang, X.R.; Zhang, Y.; Zhang, D.; Fang, Y.C. Design and characterization of FeCrCoAlMn0.5Mo0.1 high-entropy alloy coating by ultrasonic assisted laser cladding. J. Alloys Compd. 2020, 835, 155449. [CrossRef]

12. Peng, Y.B.; Zhang, W.; Li, T.C.; Zhang, M.Y.; Liu, B.; Liu, Y.; Wang, L.; Hu, S.H. Effect of WC content on microstructures and mechanical properties of FeCoCrNi high-entropy alloy/WC composite coatings by plasma cladding. Surf. Coat. Tech. 2020, 385, 125326. [CrossRef]

13. Jiang, Y.Q.; Li, J.; Juan, Y.F.; Lu, Z.J.; Jia, W.L. Evolution in microstructure and corrosion behavior of AlCoCrxFeNi high-entropy alloy coatings fabricated by laser cladding. J. Alloys Compd. 2019, 775, 1. [CrossRef]

14. Zhang, Y.; Zuo, T.T.; Tang, Z.; Gao, M.C.; Dahmen, K.A.; Liaw, P.K.; Lu, Z.P. Microstructures and properties of high-entropy alloys. Prog. Mater. Sci. 2014, 61, 1. [CrossRef]

15. Lim, X. Mixed-up matals make for stronger, tougher, stretchier alloys. Nature 2016, 533, 306. [CrossRef] [PubMed]

16. Gludovatz, B.; Hohenwarter, A.; Catoor, D.; Chang, E.H.; George, E.P.; Ritchie, R.O. A fracture-resistant high-entropy alloy for cryogenic applications. Science 2014, 345, 1153. [CrossRef]

17. Zhang, G.J.; Tian, Q.W.; Yin, K.X.; Niu, S.Q.; Wu, M.H.; Wang, W.W.; Wang, Y.N.; Huang, J.C. Effect of Fe on microstructure and properties of $\mathrm{AlCoCrFexNi}(\mathrm{x}=1.5,2.5)$ high entropy alloy coatings prepared by laser cladding. Intermetallics $2020,119,1$. [CrossRef]

18. Sha, C.H.; Zhou, Z.F.; Xie, Z.H.; Munroea, P. FeMnNiCoCr-based high entropy alloy coatings: Effect of nitrogen additions on microstructural development, mechanical properties and tribological performance. Appl. Surf. Sci. 2020, 507, 145101. [CrossRef]

19. Borkar, T.; Chaudhary, V.; Gwalani, B.; Choudhuri, D.; Mikler, C.V.; Soni, V.; Alam, T.; Ramanujan, R.V.; Banerjee, R. A combinatorial approach for assessing the magnetic properties of high entropy alloys: Role of $\mathrm{Cr}$ in $\mathrm{AlCoxCr}_{1}-\mathrm{xFeNi}$. Adv. Eng. Mater. 2017, 19, 1700048. [CrossRef]

20. Zhou, Y.J.; Zhang, Y.; Wang, Y.L.; Chen, G.L. Solid solution alloys of AlCoCrFeNiTix with excellent room-temperature mechanical properties. Appl. Phys. Lett. 2007, 90, 181904. [CrossRef]

21. Yu, Y.; Wang, J.; Li, J.S.; Kou, H.C.; Li, W.M. Characterization of BCC phases in AlCoCrFeNiTix high entropy alloys. Mater. Lett. 2015, 138, 78. [CrossRef]

22. Liu, J.; Liu, H.; Chen, P.J.; Hao, J.B. Microstructural characterization and corrosion behaviour of AlCoCrFeNiTix high-entropy alloy coatings fabricated by laser cladding. Surf. Coat. Tech. 2019, 361, 63. [CrossRef]

23. Yang, L.; Yu, T.B.; Li, M.; Zhao, Y.; Sun, J.Y. Microstructure and wear resistance of in situ synthesized Ti(C, N) ceramic reinforced Fe-based coating by laser cladding. Ceram. Int. 2018, 44, 22538. [CrossRef]

24. Dai, M.J.; Wei, C.B.; Zhou, K.S.; Zhu, M.; Hou, H.J.; Lin, S.S.; Tong, X. Properties of W/DLC/W-S-C composite films fabricated by magnetron sputtering. Trans. Nonferrous Met. Soc. China 2015, 25, 3002. [CrossRef]

25. Liu, H.; Xu, Q.; Wang, C.; Zhang, X. Corrosion and wear behavior of Ni60CuMoW coatings fabricated by combination of laser cladding and mechanical vibration processing. J. Alloys Compd. 2015, 621, 357. [CrossRef]

26. Rehr, J.J.; Albers, R.C. Theoretical approaches to x-ray absorption fine structure. Rev. Mod. Phys. 2020, 72, 621. [CrossRef]

27. Lytle, F.W. The EXAFS family tree: A personal history of the development of extended X-ray absorption fine structure. J. Synchrotron Radiat. 1999, 6, 123. [CrossRef]

28. Ravela, B.; Newville, M. ATHENA, ARTEMIS, HEPHAESTUS: Data analysis for X-ray absorption spectroscopy using IFEFFIT. J. Synchrotron Radiat. 2005, 12, 537. [CrossRef]

29. Rehr, J.J.; Kas, J.J.; Vila, F.D.; Prange, M.P.; Jorissen, K. Parameter-free calculations of x-ray spectra with FEFF9. Phys. Chem. 2010, 12, 5503. [CrossRef]

30. Harris, V.G.; Kemner, K.M.; Das, B.N.; Koon, N.C.; Ehrlich, A.E.; Kirkland, J.P.; Woicik, J.C.; Crespo, P.; Hernando, A.; Escorial, A.G. Near-neighbor mixing and bond dilation in mechanically alloyed Cu-Fe. Phys. Rev. B 1996, 54, 6929. [CrossRef] 
31. Miracle, D.B.; Senkov, O.N. A critical review of high entropy alloys and related concepts. Acta Mater. 2017, 122, 448. [CrossRef]

32. Huang, R.R.; Zhang, Q.; Xuan, Z.; Li, J.G.; Cao, T.Q.; Yao, J.H.; Xue, Y.F.; Gao, H.J.; Li, X.Y. Dynamic recrystallization-induced temperature insensitivity of yield stress in single-crystal Al1.2CrFeCoNi micropillars. Sci. China Technol. Sci. 2021, 64, 11. [CrossRef] 